\title{
UPAYA MENINGKATKAN HASIL BELAJAR IPA DENGAN MENGGUNAKAN METODE DISKUSI BERVARIASI PADA KELAS III SDN 1 LUNUK RAMBA TAHUN PELAJARAN 2016/2017
}

\author{
OLEH : Tia Normiasih*, Karyanti**
}

\begin{abstract}
Abstrak
Penelitian ini bertujuan untuk : (1) mengetahui peningkatan aktivitas belajar IPA peserta didik kelas III SDN 1 Lunuk Ramba dengan menggunakan metode Diskusi Bervariasi, (2) mengetahui peningkatan hasil belajar IPA peserta didik kelas III SDN 1 Lunuk Ramba dengan menggunakan metode Diskusi Bervariasi.

Penelitian ini di lakukan pada minggu ke-2 bulan April yang berlokasi di SDN 1 Lunuk Ramba, Desa Lunuk Ramba Kecamatan Basarang Kabupaten Kapuas. Jenis penelitian ini adalah Penelitian Tindakan Kelas (PTK) dengan subjek penelitian seluruh peserta didik kelas III SDN 1 Lunuk Ramba yang berjumlah 18 peserta didik. Teknik yang dii gunakan untuk mengumpulkan data pada penelitian ini yaitu menggunakan tes dan observasi. Analisis data menggunakan analisis data kualitatif dan analisis data kuantitatif.

Hasil penelitian ini menunjukkan bahwa : (1) aktivitas belajar IPA dengan Menggunakan Metode Diskusi Bervariasi pada peserta didik kelas III SDN 1 Lunuk ramba tahun pelajaran 2016/2017 menjadi lebih baik. (2) ada peningkataan hasil belajar IPA dengan menggunakan metode Diskusi Bervariasi pada peserta didik kelas III SDN 1 Lunuk Ramba tahun pelajaaran 2016/2017, ini terbukti dari hasil pra tindakan dengan ketuntasan klasikalm25\% dandengannilai rata-rata, pada Siklus I dengan ketuntasanklasikal 56\% dandengannilai rata-rata 61 dan Siklus II dengan ketuntasanklasikal 94\% dandengannilai ratarata 88.
\end{abstract}

\section{Kata Kunci : Hasil Belajar, MetodeDiskusiBervariasi}

\section{PENDAHULUAN}

Pendidikan merupakan usaha sadar dan terencana untuk mewujudkan suasana belajar dan proses pembelajaran agar peserta didik secara aktif mengembangkan potensi dirinya untuk memiliki kekuatan spiritual keagamaan, pengendalian diri, kepribadian, kecerdasan, akhlak mulia, serta keterampilan yang diperlukan dirinya dan masyarakat. Pendidikan meliputi pengajaran keahlian khusus, dan juga sesuatu yang tidak dapat dilihat tetapi lebih mendalam yaitu pemberian pengetahuan, pertimbangan dan kebijaksanaan. Salah satu dasar utama pendidikan adalah untuk mengajar kebudayaan melewati generasi.

Hal ini di dukung pula oleh tujuan pendidikan yang tercantum dalam UndangUndang RI No. 20 tahun 2003 tentang Sistem Pendidikan Nasional Pasal 1 ayat(1) yang menyatakan bahwa Pendidikan adalah usaha sadar dan terencana untuk mewujudkan suasana belajar dan proses pembelajaran dengan peserta didik secara aktif membangun potensi dirinya untuk memahami kekuatan spiritual keagamaan, pengendalian diri, kepribadian, kecerdasan, akhlak mulia serta keterampilan yang di perlukan dirinya, masyarakat, bangsa dan 
negara. Menurut Undang-Undang 2003.(Titik Sri Lestari, 2009: 1)

Menurut Permendiknas Nomor 22 Tahun 2006 tentang standar isi untuk satuan pendidikan dasar dan menengah di jelaskan bahwa tujuan mata pelajaran IPA di harapkan dapat menjadi wahana bagi peserta didik untuk mempelajari diri sendiri dan alam sekitar, serta prospek pengembangan lebih lanjut dalam menerapkannya dalam kehidupan sehari-hari.

Pada saat ini pentingnya penguasaan keterampilan berpikir, khususnya pada siswa $\mathrm{SD}$, telah menjadi isu sentral dalam sistem pendidikan Indonesia. Di dalam standar isi di nyatakan pula bahwa pembelajaran IPA di SD/MI bertujuan agar peserta didik memiliki keterampilan mengembangkan keterampilan proses untuk menyelidiki alam sekitar, memecahkan masalah dan membuat keputusan. Sedangkan di dalam standar proses (Permendiknas nomor 41 tahun 2007), secara eksplitisi dinyatakan bahwa da dalam pelaksanaan pembelajaran, guru memberikan kesempatan siswa berpikir, menganalisis, menyelesaikan masalah dan bertindak tanpa rasa takut.

Oleh karena itu, tugas pendidik bukan hanya sekedar mengajar tetapi juga bagaimana cara menanamkan sikap-sikap atau pelajaran-pelajaranyang sudah di dapatkan agar bisa di terapkan ke dalam kehidupan peserta didik.

Menurut Rusbult (Karti Soeharto, 2011:89) tujuan utama guru dalam pembelajaran adalah "melatihkan keterampilan berpikir yang lebih efektif kepada siswanya".

Selain itu, tugas seorang pendidik adalah bagaimana menerapkan beberapa keterampilan mengajar agar seluruh tujuan pembelajaran IPA dapat tercapai dalam mata pelajaran IPA. Selain itu, pembelajaran IPA juga memberikan pengetahuan dasar dari konsep yang bermanfaat untuk kehidupan sehari-hari.

Ilmu Pengetahuan Alam merupakan mata pelajaran yang menyenangkan karena pada mata pelajaran ini dapat kita lihat dan alami secara langsung di alam. Namun, sebagian peserta didik merasa bahwa mata pelajaran ini membosankan. Mungkin bagi peserta didik membosankan karena peserta didik tidak mengalami nya secara langsung, peserta didik hanya mendengarkan saja materi yang di berikan tanpa melakukan kegiatan. Dalam pembelajaran IPA pendidik bisa membawa mereka untuk mengamati langsung alam kita, melakukan praktik dan lain hal yang menyenangkan. Selain itu, para pendidik juga dapat menggunakan berbagai macam metode yang di gunakan dalam proses pembelajaran agar pembelajaran menjadi bermakna dan menyenangkan sehingga peserta didik memiliki motivasi untuk mengikuti proses pembelajaran.

Banyak metode-metode yang dapat di lakukan dalam proses pembelajaran. Dan dengan menggunakan metode yang di gunakan, di harapkan dapat meningkatkan hasil belajar peserta didik terutama hasil belajar IPA.

Berdasarkan hasil observasi yang peneliti lakukan di SDN 1 Lunuk Ramba yang berjumlah 17 orang peseta didik pada hari Rabu 08 Maret 2017, kelemahan proses belajar khususnya dalam mata pelajaran IPA, dapat di identifikasi dari rendahnya motivasi belajar IPA .Selain itu, pemikiran mereka tentang pelajaran IPA yang rumit serta membosankan membuat peserta didik kurang tertarik dengan pelajaran tersebut. Pelajaran IPA merupakan pelajaran yang sangat menarik karena merupakan pelajaran yang ada di lingkungan. Selain itu, dalam pembelajaran IPA kita bisa menggunakan alam sebagai proses pembelajaran sehingga apa yang peserta didik pikirkan tentang 
pelajaran IPA yang mereka anggap membosankan akan sangat menyenangkan apalagi jika memanfaatkan apa saja yang ada di alam.

Pendidik sangat baik dan maksimal dalam memberikan dan menyampaikan materi pelajaran. Namun, metode yang di gunakan pendidik kurang bervariasi sehingga peserta didik kurang memiliki motivasi untuk mengikuti proses pembelajaran serta media yang di gunakan pun juga kurang bervariasi.

Hasil belajar peserta didik yang di peroleh dari ulangan harian pada mata pelajaran IPA masih banyak yang belum tuntas atau masih di bawah KKM. Pada pembelajaran IPA di tentukan KKM dengan nilai pembelajaran IPA di yaitu 60 , rata-rata nilai peserta didik kelas III SDN 1 Lunuk Ramba di bawah KKM sebanyak 9 orang = $52,94 \%$ dan di atas KKM sebanyak 8 orang $=47,05 \%$ dengan rincian nilai tertinggi 90 dan untuk nilai terendah 40 .

Dari beberapa permasalahan yang di jelaskan peneliti tersebut, terlihat bahwa keterampilan guru, aktivitas serta hasil belajar peserta didik masih kurang maksimal, akibatnya di perlukan adanya peningkatan kualitas pembelajaran IPA di SDN 1 Lunuk Ramba. Berdasarkan permasalahan tersebut, guru di harapkan mampu menciptakan suasana pembelajaran yang bisa meningkatkan minat serta motivasi belajar peserta didik.

Mengingat pentingnya pelajaran IPA, peneliti mengajukan salah satu metode pembelajaran yaitu metode diskusi bervariasi, yang mana dengan metode ini bisa membuat peserta didik merasa bersemangat untuk mengikuti pelajaran sehingga menumbuhkan motivasi mereka serta mereka juga akan lebih aktif mengikuti proses pembelajaran.
Maka dari itu, peneliti tertarik untuk melakukan penelitian di SDN 1 Lunuk Ramba dengan judul "Upaya Meningkatkan Hasil Belajar IPA dengan Menggunakan Metode Diskusi Bervariasi pada Peserta Didik Kelas III SDN 1 Lunuk Ramba Tahun Pelajaran 2016/2017”.

Adapun alasan yang mendasari dari pengambilan judul ini agar peserta didik lebih aktif dalam mengikuti proses pembelajaran seta memudahkan peserta didik memahami materi yang di ajarkan. Selain itu, dengan metode yang di gunakan ini di harapkan dapat meningkatkkan hasil belajar peserta didik serta meningkatkan motivasi belajar.

\section{METODE PENELITIAN}

Data yang di kumpulkan dari setiap siklus akan di analisis menggunakan metode Mixed Methods atau metode kombinasi antara kualitatif dan kuantitatif. Creswell (Sugiyono, 2013:244) menyatakan bahwa "Metode penelitian kombinasi (mixed method) akan berguna bila metode kuantitatif atau metode kualitatif secara sendiri-sendiri tidak cukup akurat di gunakan untuk memahami permasalahan penelitian atau dengan menggunakan metode kualitatif dan kuantitatif secara kombinasi akan dapat memperoleh pemahaman yang paling baik sehingga di peroleh data yang lebih komprehensif, valid, reliabel dan obyektif (bila di bandingkan dengan metode)."

Dalam penelitian ini analisis data yang di gunakan untuk menjawab permasalahan yang telah di kemukakan pada Bab I adalah analisis kualitatif dan kuantitatif.

\section{Kualitatif}

Data kualitatifyaitu di gunakanuntukmenunjukkanaktifitaspesert adidik yang terjadipadasaat proses 
pembelajaranberlangsung yang dapat di perolehdarilembaraktivitaspesertadidik.

Data yang ada di kumpulkandankemudian di buatpresentasi yang kemudian di deskripsikan. Observasi yang di sediakanyaitulembarobservasipesertadidik berdasarkanaktifitas yang ingin di amatiuntukmengetahuikeefektifanpembel ajaranmenggunakanMetodeDiskusiBervar iasi. Data penelitianaktifitaspesertadidik di dapatkandariskortiappesertadidik.

\section{Kuantitatif}

Data kuantitatifini di gunakanuntukmelihatpeningkatanhasilbel ajarpesertadidiksetelahmenggunakanmeto depembelajarandiskusibervariasi. Data kuantitatif di dapatdaripenilaianlatihandantes (pre testdanpost test).

\section{a. Penilaian Rata-rata}

Penelitimenjumlahkannilaiyang diperolehpesertadidik yang kemudian di

bagidenganjumlahpesertadidikkelasters ebutsehingga di perolehnilai ratarata.Untukmencarinilai rata-rata denganmenggunakanrumussebagaiberi kut:

$$
\mathrm{M}=\frac{\sum X}{n}
$$

Keterangan :

M :Nilai rata-rata kelas

$\sum X \quad$ : Jumlah semua nilai siswa

$\mathrm{N}$ : jumlahsiswa

\section{b. PresentaseKetuntasanBelajar}

Dalampenelitianiniterdapatduakateg oriketuntasanbelajaryaituketuntasansecara individual danklasikal. Ketuntasanbelajarsecara individual di dapat KKM yang di tetapkansekolahuntukpembelajaran IPA adalah 60 untuk di nyatakantuntasdannilaikurangdari 55 di nyatakanbelumtuntas.

Sedangkanketuntasanbelajarklasikalyaitu mengukurtingkatkeberhasilanketuntasanb elajarpesertadidikmenyeluruh.

Untukmengetahuiketuntasanbelajark lasikalpesertadidikdenganmenggunakanru mussebagaiberikut:

$$
\mathrm{TB}=\frac{\sum s \geq 60}{n} \times 100 \%
$$

Keterangan :

TB =Ketuntasanbelajarklasikal, minimal $85 \%$

$\sum \mathrm{S} \geq 60 \quad=$ Jumlahpesertadidik yang mendapatnilailebihdariatausamad engan 60

$100 \%=$ Bilanganpengalitetap

$\mathrm{N}=$ Banyakpesertadidik

KriteriaKetuntasan:

$$
85-100=\text { Tuntas }
$$

0- $84=$ BelumTuntas

Hasilanalisisinijuga di jadikansebagaibahanrefleksidalammempe rbaikirancanganpembelajaranataubahkans ebagaibahanpertimbangandalampenentua $\mathrm{n}$ model pembelajaran yang tepat. 


\section{HASIL PENELITIAN PEMBAHASAN}

\section{Pra Tindakan}

Data pra tindakan terdiri atas data hasil tes awal (pree test). Data awal ini bertujuan untuk mengetahui tingkat kemampuan awal peserta didik terhadap materi yang akan di jadikan topik pembelajaran sebelum penelitian tindakan kelas berlangsung. Adapun bentuk teks yang di lakukan dengan memberikan sebanyak 10 soal isian yang di jawab peserta didik sebelum pembelajaran IPA dengan materi Energi dan Manfaatnya menggunakan Metode Diskusi Bervariasi. Dalam kegiatan pra tindakan ini, sebagian peserta didik belum mengalami ketuntasan pembelajaran sesuai KKM yang telah di tentukan oleh sekolah.

Berdasarkanhasil data yang di perolehdapat di simpulkan bahwa ketuntasan belajar peserta didik pada materi "Sumber Energi dan Manfaatnya" untuk mata pelajaran IPA masih banyak di bawah KKM atau masih banyak hasil belajar peserta didik belum tuntas, $75 \%$ peserta didik yang memperoleh nilai tidak tuntas dan hanya $25 \%$ peserta didik yang memperoleh nilai tuntas. Pembelajaran daapat di katakan tuntas apabila presentase dalam evaluasi pembelajaran mencapai $85 \%$ dan memperoleh nilai rata-rata $\geq 60$.

Berdasarkan data awal inilah, peneliti merasa perlu untuk melakukan tindakan kelas dalam dua siklus untuk pembelajaran IPA pada materi Sumber Energi dan Manfaatnya dengan menerapkaan Metode Diskusi Bervariasi pada Kelas III SDN 1 Lunuk Ramba.

\section{Siklus I}

Pada tahap siklus I aktivitas guru dan peserta didik mengalami peningkatan sedikit dibandingkan dari tahap pra
tindakandenganmenggunakanMetodeDiskusi Bervariasi. Berdasarkan hasil pengamatan yang di lakukan oleh dua pengamat, pada pengamatan aktivitas guru termasuk dalam kategori cukup baik, karena pada pengamat I memberikan nilai rata-rata 2,72 Sedangkan pengamatan II memberikan nilai rata-rata 2,81 . Sehingga di peroleh hasil rata-rata dari kedua pengamat yaitu 2,77 yang termasuk dalam kategori cukup baik.

Sedangkan berdasarkan pengamatan dua pengamatan di atas dapat di ketahui bahwa hasil pengamatan yang di lakukan terhadap peserta didik dengan kategori cukup. Pengmatan 1 memberikan nilai ratarata 2,63 (cukup baik) dan pengamat 2 memberikan nilai rata-rata 2, 63 (cukup baik). Sehingga di peroleh hasil rata-rata dari dua pengamatan adalah 2,63 yang termasuk dalam kategori nilai cukup baik.

\section{Siklus II}

Pada tahap siklus II aktivitas guru dan peserta didik mengalami peningkatan yang baik, Berdasarkan pengamatan yang di lakukan oleh dua pengamat di atas, dapat di ketahui bahwa hasil pengamatan terhadap aktivitas guru dengan kategori baik. Pengamat I memberikan nilai rata-rata 4 (baik),dan pengamat II memberikan nilaai rata-rata 3,90 (baik). Sehingga di peroleh hasil rata-rata dari dua pengamat yaitu 3,95 yang termasuk dalam kategori baik.

Berdasarkan pengamatan yang di lakukan oleh dua pengamat terhadap aktivitas peserta didik dengan kategori baik. Pengamat I memberikan nilai 3,81 (baik) daan pengamat II memberikan nilai 3,90 (baik). Sehingga di peroleh hasil rata-rata dari dua pengamat yaittu 3,86 yang termasuk dalam kategori baik.

Berdasarkan keterangan tabel di atas, pada siklus II terjadi peningkatan terhadap aktivitas guru dan aktivitas peserta didik dalam proses pembbelajaran dengn 
menggunakan Metode Diskusi Bervariasi lebih baik dari siklus I. Hal ini terbukti bahwa peneliti telah berhasil meningkatkan aktivitas guru dan peserta didik.

\section{KESIMPULAN}

1. Aktivitas belajar IPA menjadi baik dengan mengunakan Metode Diskusi Bervariasi pada peserta didik kelas III SDN 1 Lunuk Ramba tahun pelajaran 2016/2017. Hal ini dapat di lihat dari hasil observasi pada aktivitas belajar peserta didik pada siklus I dengan kategori cukup

\section{DAFTAR PUSTAKA}

Karti Soeharto.(2011). Inovasi Jurnal Pembinaan dan Pengembangan Pendidikan Pusat Pembinaan dan Pengembangan Pendidikan, Surabaya. UPT P4 Universitas Negeri Surabaya. baik dengan skor rata-rata 2,63 dan pada siklus II terjadi peningkatan skor rata-rata 3,86 dengan kategori baik.

2. Ada peningkatan hasil belajar IPA peserta didik kelas III SDN 1 Lunuk Ramba dengan menggunakan Metode Diskusi Bervariasi, ini terbukti dari hasil yang di lakukan pada pra tindakan dengan ratarata 49 daan ketuntasan klasikal 25\%, pada Siklus I dengan rata-rata 61 dan ketuntasan klasikal 56\%, dan Siklus II dengan rata-rata 88 dan ketuntasan klasikal 94\%

Muliawan, J.U. (2016).Model Pembelajaran Spektakuler, Lampung : Ar-Ruzz Media.

Sugiyono.(2013).MetodePenelitianKuantitati $f$ Kualitatif dan $R \& D$ : Alfabeta, CV. Bandung 